\title{
Special Consideration in Treating Patients of Overlap Between Asthma and COPD
}

\author{
So Ri Kim ${ }^{1,2}$ and Yang Keun Rhee ${ }^{1}$ \\ ${ }^{1}$ Department of Internal Medicine, \\ ${ }^{2}$ Research Center for Pulmonary Disorders, \\ Chonbuk National University Medical School, Jeonju, \\ South Korea
}

\section{Introduction}

Asthma and chronic obstructive pulmonary disease (COPD) are distinct in pathobiological characteristics. Asthma is a disease with its origins in child hood, is related to allergies and eosinophils, and is best treated by targeting inflammation, whereas COPD is related to adults who smoke and to neutrophils, and is best treated with bronchodilators and the removal of risk factors. However, this distinction is not always clear-cut and there is a considerable overlap in pathogenesis and clinical features; patients with severe asthma may present with fixed airway obstruction while patients with COPD may have hyperresponsiveness and eosinophilia (Kim \& Rhee, 2010). In fact, the classification of patients having asthma or COPD may vary day-to-day based on established diagnostic criteria, due to their overlap and inherent variability in bronchodilator responsiveness (Calverley et al., 2003). Moreover, several hypotheses/theories have been proposed to explain whether they are in a single disease entity.

In accord with this concept for the two diseases, recent diagnostic approaches appear to be concentrated on various and specific phenotypes because of their different therapeutic responses to the standard treatment for each disorder depending on the phenotypes. The refractory asthmatic patients share several characteristics of patients with COPD, suggesting that drugs in discovery for COPD might also be effective in treating severe asthma (Barnes, Mar 2008, Dec 2008). In fact, many new drugs under pre- or clinical trials are expected to be effective in both diseases and overlapping situations. However, there remains still a need to extend novel drug development and to investigate the mechanisms and treatment of overlapping asthma and COPD. In this chapter, we will review these special therapeutic considerations for severe or refractory entity, i.e., overlap of two major airway obstructive disorders, asthma and COPD.

\section{The overlap between asthma and COPD}

Asthma and COPD are pulmonary disorders characterized by various degrees of airflow limitation, inflammation, and tissue remodeling. Classical definition of two disorders describes the physiological and anatomic extremes of asthma and COPD and allows them to 
be recognized as distinct disease entities. Actually, asthma has been differentiated from pure COPD through several condition described as follows; i) youthful onset, ii) non-smokers, iii) episodic and completely reversible airway obstruction and airway hyperresponsiveness, and iv) allergic history including the association with rhinitis. In addition, a dysregulated $\mathrm{T}$ helper cell (Th) type 2 inflammatory response is responsible for the eosinophilic and mononuclear cell infiltration, mucous metaplasia, airway remodeling are seen in asthma patients and characterize asthma. However, each disorder has a very wide spectrum of clinical and pathobiological phenotypes thereby in considerable patients the diagnosis becomes vague, confusing, and being overlapped (Kim \& Rhee, 2010). Thus, the current classification of obstructive airway diseases is not adequate to precisely treat COPD and asthma. Recently, different statistical techniques have been used to better understand and describe the multiple dimensions of airway diseases with the ultimate goal being identification of distinct subgroups of patients with different prognosis or response to treatment (Shirtcliffe et al., 2011).

Asthma and COPD are representative chronic inflammatory lung diseases. In both conditions, inflammation is associated with episodic exacerbation and/or structural alteration at large and small airway levels (Guerra, 2005; Jeffery, 2004). These can result in a transient phenotypic overlap or a combined syndrome with characteristics of both diseases.

Exacerbation of asthma and COPD is a clinically significant event and frequently associated with a decline in lung function and symptomatic aggravation (Gibson \& Simpson, 2009). During exacerbation, airway inflammation becomes more exaggerated than in the mild and stable disease states, thereby the inflammation pattern changes (Mauad \& Dolhnikoff, 2008). Neutrophil recruitment is a prominent feature of acute exacerbation of chronic asthma (Lamblin et al., 1998), probably owing to respiratory tract infection by viruses (Fahy et al., 1995; Wark et al., 2002). Furthermore, neutrophilic inflammation in the absence of eosinophils is largely present in sudden-onset fatal asthma, and neutrophil numbers are highly elevated in status asthmaticus (Lamblin et al., 1998; Tsokos \& Paulsen, 2002). Thus, severe and fatal asthma may be mediated by neutrophils, which is quite different from the classical Th2-driven eosinophilic form. In COPD patients, an allergic profile of inflammation can occur, particularly during exacerbation. Airway eosinophilia is observed in chronic bronchitic patients with exacerbation and is associated with the upregulation of RANTES in the airway epithelium (Saet et al., 1994; Zhu et al., 2001). These observations indicate that inflammatory characteristics of asthma and COPD are interchangeable during exacerbation and infection.

The cytokine profile is also affected by disease severity. During exacerbation, Th1/Th2 patterns are reversed to some degree in each disease. Several studies have demonstrated that the level of IL-17 is elevated in asthma and COPD and is correlated with the presence of neutrophils and the decrease of lung function (Bullens et al., 2006; Matsunaga et al., 2006; Molet et al., 2001; Wong et al., 2001). The elevation of IL-17 level is associated with increased neutrophilic inflammation during severe asthma or acute exacerbation (Wong et al., 2001). In COPD, the role of IL-17 remains unclear, although the importance of IL-17 in stimulating chemokine production and the involvement of neutrophils and macrophages in promoting COPD pathogenesis suggest a potential connection (Curtis et al., 2007). 
Disease exacerbation in both asthma and COPD can lead to an accelerated decline in lung function (Stein et al., 1999; Stern et al., 2007). Previous reports have shown an association between severe asthma exacerbation and an accelerated decline in forced expiratory volume in $1 \mathrm{~s}$ (FEV1), to a degree similar to that seen in patients with smoking and COPD (Vonk et al., 2003). Another important observation is that the decline in FEV1 seen in patients with infrequent exacerbation is similar to that in a population without asthma. These findings suggest that repetitive episodes of exacerbation may result in fixed airflow obstruction in asthma and contribute to the phenotypic overlap between asthma and COPD.

Decreased distensibility and increased collapsibility of small airways including alveoli are prominent in asthmatic emphysema, whereas loss of elastic recoil is an important factor in the dynamic collapse of the airway in COPD (James \& Wenzel, 2007). Currently, there are at least two major pathophysiological mechanisms responsible for the development of emphysema: protease-antiprotease imbalance and apoptosis of structural cells (Spurzem \& Rennard, 2005). Increased elastin degradation and enhanced expression of proteases have been documented in asthma patients (Bousquet et al., 1996; James \& Wenzel, 2007). In IL-13overexpressing transgenic mice, emphysema and the increased expression of a variety of matrix metalloproteinases (MMPs) and cathepsins have been observed (Zheng et al., 2000). Intervention that neutralize MMPs or cathepsins has been shown to dramatically ameliorate IL-13-induced emphysematous responses. These findings suggest that IL-13 has the ability to induce alveolar remodeling responses in asthmatics. Moreover, in human asthma patients, the numbers of eosinophils, $\mathrm{CD} 4{ }^{+} \mathrm{T}$-cells, and macrophages are increased in alveolar tissue at the time symptoms appeared (Kraft et al., 1996, 1999). Furthermore, the degree of eosinophilic inflammation correlates positively with lung volume in asthma patients (Sutherland et al., 2004). These data indicate that destruction of distal airways is a consequence of a chronic, long-lasting injury, which affects lung function in both COPD and asthma.

In addition, in COPD, there is evidence for remodeling, fibrosis, and inflammation in epithelium, reticular basement membrane, airway smooth muscles (ASM), and mucous glands, albeit with patterns different from those seen in asthmatics (Bosken et al., 1990; Nagai et al., 1985; Wright et al., 1983). Furthermore, bronchodilator reversibility and AHR may be present in a significant proportion of COPD patients (Kerstjens et al., 1993). Poorer pulmonary function is associated with a greater magnitude of AHR, and increasing severity of airway hyperresponsiveness is associated with faster rates of decline in lung function in continuing smokers (Tashkin et al., 1996).

Taken together, both states of transient overlapping with exacerbation and permanent/chronic structural changes between asthma and COPD may exhibit severe phenotype and respond poorly to standard treatment for each disease.

\section{Need for new therapeutic concept for overlap between asthma and COPD}

There is now sufficient evidence to suggest that both asthma and COPD are complex heterogeneous disorders including overlapped features each other with distinct risk factors, pathophysiological processes, natural history, and treatment responses. However, current treatment guidelines for COPD and asthma are based on randomized trials of highly selected subgroups of patients, especially the very typical phenotypic group, i.e., Th2- 
predominant asthma and pure COPD (Shirtcliffe et al., 2011). Therefore, the major unmet needs of current therapies include better treatment of severe and refractory disease entities such as overlap between asthma and COPD. In addition, considering the poor and different responses to current therapy in patients with overlap, the ultimate goal of treatment targeted to this group can be achieved when the interrelationship between overlapping situation and its cellular and molecular basis is understood. In fact, there are enormous efforts to find the pharmacological therapeutic ways to control these specific phenotypic conditions worldwide.

\section{New therapeutic approaches for overlap between asthma and COPD}

\subsection{Bronchodilators}

Bronchodilators are an important component for pharmacologic approaches preventing and relieving bronchoconstriction. Recent popular bronchodilators are $\beta_{2}$-agonists with long action duration (long acting $\beta_{2}$-agonist, LABA) such as salmeterol and formoterol, which last for over 12 hours. There are now several even longer-acting $\beta_{2}$-agonists (ultra-LABA) in development, including indacaterol, carmoterol, GW-642444, and BI-1744, which have a duration of action $>24$ hours and are suitable for once daily use (Cazzola \& Matera, 2009). A once daily muscarinic antagonist, tiotropium bromide, is less effective as a bronchodilator in asthma than the $\beta_{2}$-agonists and is used predominantly in COPD, but might be a useful addon therapy in some patients with severe asthma (H.W. Park et al., 2009). Several new classes of bronchodilators including other once daily muscarinic antagonists are also in development. However, there are lots of challenges and hurdles to overcome bronchodilators' weaknesses as a single therapeutic agent.

\subsection{Novel corticosteroids}

Inhaled corticosteroids (ICS) are the most effective anti-inflammatory therapy for asthma and COPD. In addition, in case of asthma, corticosteroids are used as fixed combination inhalers, i.e., LABA plus corticosteroid, and to date, this combination therapy is known to be the most effective available therapy based on their synergistic effects. However, all currently available ICS are absorbed from the lung and thus have the potential for systemic side effect. This has led to a concerted effort to find safer ICS, with reduced oral bioavailability, reduced absorption from the lung or inactivation in the circulation. Moreover, airway inflammation in COPD responds poorly to corticosteroid administration (Barnes \& Stockley, 2005; Culpitt et al., 1999; Keatings et al., 1997), presumably because it is associated with neutrophils, CD8+T lymphocytes, and CD68+ macrophages, cells that are minimally inhibited by corticosteroids. Since asthma exacerbation exhibits mixed inflammatory pattern of asthma and COPD, in the case of overlap between asthma and COPD, the therapeutic efficacy of current corticosteroid to asthma is attenuated. To achieve disease modification, reductions in the frequency and severity of acute exacerbations and effective suppression of asthmatic and COPD-type airway inflammation, new corticosteroids and/or anti-inflammatory strategies are required. Actually, dissociated steroids designed to separate the side effect mechanisms from the anti-inflammatory mechanisms are expected to have a greater effect on enhancement of transcription for anti-inflammatory genes, and thus might have a better therapeutic efficacy with the reduction of side effects (Schaecke et al., 2004). On the other hand, nonsteroidal selective glucocorticoid receptor activators (SEGRA), such as AL-438 and 
ZK-216438, are in development, although the effect of these drugs may not be efficacious as pre-existing corticosteroids.

\subsection{Modulation of cytokines; IL-17}

Several cytokines act as important players in pathogenesis of asthma and COPD (Barnes, 2008). As for asthma, Th2 cytokines have been thought to play a major role in its pathobiology traditionally. Inhibition of Th2 cytokine, IL-4 is proven to be disappointing, but there is a continuing interest in blocking IL-13, a related cytokine that regulates IgE formation, particularly in severe asthma. In fact, several IL-13 and IL-4R $\alpha$ blocking antibodies are now in clinical trials but to date, clinical studies in severe asthma have also been disappointing (Chiba et al., 2009; Wenzel et al., 2007). Therefore, recent therapeutic approach for asthma and COPD is deviated to develop the drugs for these severe and mixed phenotypic groups. As one of hopeful candidates, mepolizumab is shown to reduce exacerbation in a particular subset of patients who have persistent sputum eosinophilia (Haldar et al., 2009; Nair et al., 2009).

IL-17, the cytokine being studied most actively nowadays, has attracted interest as a target in severe asthma as it might be a mediator of neutrophilic inflammation in severe asthma (James \& Wenzel, 2007). Given the role of IL-17 in the regulation of growth factors that promote granulopoiesis and production of chemokines that are involved in recruitment neutrophils, IL-17 plays a pivotal role in the neutrophil responses in the lung. In addition to severe asthma, steroid-resistant asthma may also feature a neutrophil-dependent component (Louis \& Djukanovic, 2006). In fact, neutrophils are largely steroid insensitive, and corticosteroids inhibit neutrophil apoptosis (Cox, 1995; Schleimer et al., 1989), perhaps explaining the increase in neutrophilia in severe and steroid resistant asthmatics. Another key neutrophil protease, MMP-9, is a primary MMP enhanced in asthmatics, and the level of MMP-9 correlates with asthma severity (Cundall et al., 2003; Wenzel et al., 2003). Furthermore, IL-17 increases MMP-9 level via recruitment of neutrophils to the lung (Prause et al., 2004).

Yet, the role of IL-17 and Th17 cells in COPD remains largely speculative, although the importance of IL-17 in stimulating chemokine production and the role of neutrophils and macrophages in promoting COPD pathogenesis have led to great deal of interest on their interrelationship (Curtis, 2007). In addition, another possible link derives from IL-17's ability to drive MMP-9 production, which may directly link to tissue destruction observed in COPD (Prause et al., 2004).

Taken together, these observations suggest a role of neutrophils in mediating severe and steroid-resistant asthma (Foley \& Hamid, 2007; Kamath et al., 2005; Louis \& Djukanovic, 2006), indicating the therapeutic potential of blockade of IL-17 for the control of severe and steroid resistant asthma such as overlap with COPD.

\subsection{Regulation of lipid mediators}

To date, the only mediator antagonists currently used in therapy for airway inflammatory disorders are anti-leukotrienes, which block cysteinyl leukotriene (cysLT) type 1-receptors. Although these drugs are much less effective than ICS, a recent study has revealed that 
cysLTs are implicated in sub-epithelial fibrosis, one of structural changes in airway remodeling, in asthmatic airways through the induction of IL-11 expression (Lee et al., 2007). Several other drugs that inhibit receptors or synthesis of lipid mediators are currently in development. Among them, some novel 5'-LO and 5'-LO-activating protein (FLAP) inhibitors are more effective in patients with neutrophilic inflammation because they block the production of leukotriene (LT)B4. However, an LTB4 receptor (BLT1) antagonist had no effect in mild asthma (Evans et al., 1996).

\subsection{Phosphodiesterase (PDE) inhibitors; targeting PDE4}

PDE4 inhibitors have been in development for many years. Interest in this class of compound arose in the 1980s when it became clear that methylxanthines such as theophylline, which had been widely used for its bronchodilator action since the 1930s, were difficult to use and could be dangerous because of its side effects. As a consequence, safer substitutes have been sought. At the same time, it was discovered that theophylline is an nonselective inhibitor of PDEs. There are multiple families of PDEs; one of these families, PDE4, is expressed in ASM and in immune and pro-inflammatory cells (Torphy, 1988, 1990, 1991, 1998). PDE4 inhibitors have a wide spectrum of anti-inflammatory effects, inhibiting T cells, eosinophils, mast cells, ASM cells, epithelial cells, and nerve cells, and are very effective in animal models of asthma (Chung, 2006). In accordance with these findings, an oral PDE4 inhibitor, roflumilast, has an inhibitory effect on allergen-induced responses in asthma and also reduces symptoms of asthma and lung function, similar to low doses of ICS (Bousquet et al., 2006). In addition to asthma, COPD is also the target airway disorder of PDE4 inhibitors with improving FEV1 and preventing the acute exacerbation (Calverley et al., 2007, 2009; Rabe et al., 2005). Therefore, PDE4 inhibitors are expected to use for treating COPD associated with asthma or patients at risk of transient overlapping situation such as acute exacerbation.

\subsection{Adenosine receptor inhibitors}

One inflammatory mediator common to both airway diseases is adenosine, making its receptor signaling pathway to be a therapeutic target for asthma and COPD. Adenosine levels have been shown to increase in patients with asthma and COPD and in animal models having features of chronic airway disease (Zhou et al., 2009). Moreover, inhalation of adenosine induces bronchoconstriction in patients with asthma and COPD (Caruso et al, 2007). A non-selective adenosine receptor antagonist, theophylline, improves lung function and symptoms in asthma and COPD (Caruso et al, 2007; Zhou et al., 2009). Furthermore, adenosine receptors are expressed on most, if not all, inflammatory and stromal cell types involved in the pathogenesis of asthma and COPD. Extracellular adenosine elicits its effects by interacting with four adenosine receptors: A1R, A2AR, A2BR, and A3R (Polosa \& Blackburn, 2009). Adenosine receptor signaling systems are complex, displaying different and specific actions in various inflammatory responses. Studies with animal models of airway disease have suggested that $\mathrm{A} 1, \mathrm{~A} 3$, and $\mathrm{A} 2 \mathrm{~B}$ antagonists may be useful for the treatment of asthma and COPD, although their therapeutic efficacy remains to be fully evaluated. Various selective adenosine receptor antagonists are under preclinical or clinical studies with patients of asthma and/or COPD. 


\subsection{Kinase inhibitors: Nuclear factor (NF)-kB, mitogen-activated protein kinase (MAPK), and phosphoinositide-3 kinase (PI3K) signaling pathways}

Generally, kinases are a pivotal component of biological actions in living things. In airway inflammation, a tremendous number of kinases are implicated and play critical roles. NF- $\kappa \mathrm{B}$ regulates expression of various inflammatory genes that are involved in airway diseases (Adcock et al., 2006). Indeed, small molecule inhibitors of the key enzyme IKK2/IKKb (inhibitor of $\kappa \mathrm{B}$ kinase) block inflammation induced by NF- $\kappa \mathrm{B}$ activation and are now in preclinical test (Karin et al., 2004). In addition, p38 MAPK activates similar inflammatory genes to NF- $\mathrm{KB}$, and is activated in cells from patients with severe asthma (Bhavsar et al., 2008). Several small molecule inhibitors are now in clinical study for the treatment of inflammatory diseases (Cuenda \& Rousseau, 2007). Most of all, PI3K signaling is the most anticipated target of future drugs for asthma and COPD. In particular, the major focus of interest has been $\mathrm{PI} 3 \mathrm{~K} \gamma$ and $\delta$ isoforms in respiratory disorders including asthma. PI3K $\gamma$ is important for chemotactic responses, and selective inhibitors are in development, whereas PI3K $\delta$ activation results in reduced steroid responsiveness through reducing histone deacetylase (HDAC) 2 activity, thus PI3K $\delta$ inhibitors could potentially reverse corticosteroid resistance in severe asthma (To et al., 2010). In addition, selective inhibition of the PI3K $\delta$ signaling pathway suppresses IL-17 expression through regulation of NF- $\kappa \mathrm{B}$ activity in asthma (Park et al, 2010). These findings suggest that PI3K $\gamma / \delta$ targeting agent can be a promising therapeutic tool for the treatment and prevention of severe asthma having COPD natures and acute exacerbation.

\subsection{Targeting regulatory $\mathrm{T}$ cells}

Regulatory $\mathrm{T}$ cells in patients with corticosteroid resistance produce less IL-10 but this can be restored with vitamin D3 supplementation in vitro (Xystrakis et al., 2006). Additionally, in corticosteroid-resistant patients with asthma, intake of vitamin D3 enhances IL-10 secretion from regulatory $\mathrm{T}$ cells in response to dexamethasone (Xystrakis et al., 2006). However, the therapeutic effects of vitamin D3 and its analogue 1a,25-vitamin D3 (calcitriol) on refractory or steroid resistant asthma remains unclear and need to test in large-scaled clinical trials.

\section{Conclusion}

Despite the distinct clinical phenotypic features of asthma and COPD, there is considerable overlap of symptoms and pathogenesis, and several hypotheses have been proposed regarding the status of asthma and COPD as a single disease entity. Overlapping features may occur not only in a permanent form but also as a transient symptom, as in exacerbation. In accordance with this, recent therapeutic approaches have concentrated on a target common to the pathogenesis of both asthma and COPD. Classic pharmacologic agents are innovating as new drugs to avoid significant side effects and to cover the patients at risk frequent exacerbation and refractory severe disease status in asthma and COPD. Novel candidate targets include various kinase pathways, adenosine receptors, lipid mediators, and PDE4, and almost of them are under preclinical or clinical trials. However, it still requires enormous efforts to develop novel classes of drugs overcoming the limitations of pre-existing medicines and to investigate the mechanisms and treatment of overlapping asthma and COPD. 


\section{Acknowledgment}

We thank Professor Yong Chul Lee (Chonbuk National University Medical School, Jeonju, South Korea) for the helpful discussion throughout the preparation of this work and Professor Mie-Jae Im (Chonbuk National University Hospital, Jeonju, South Korea) for critically reading this manuscript. This work was supported by a grant from the Korea Healthcare Technology R\&D Project, Ministry for Health, Welfare, and Family Affairs, Republic of Korea (A084144) (to S.R.K).

\section{References}

Adcock, I.M., Chung, K.F., Caramori, G., \& Ito, K. (2006). Kinase inhibitors and airway inflammation. European Journal of Pharmacology, Vol.533, No.1-3, (March 2006), pp. 118-132, ISSN 0014-2999

Barnes, P.J. \& Stockley, R.A. (2005). COPD: current therapeutic interventions and future approaches. European Respiratory Journal, Vol.25, No.6, (June 2005), pp. 1084-1106, ISSN 0903-1936

Barnes, P.J. (2008). Immunology of asthma and chronic obstructive pulmonary disease. Nature Review Immunology, Vol.8, No.3, (March 2008), pp. 183-192, ISSN 1474-1733

Barnes, P.J. (2008). The cytokine networks in asthma and chronic obstructive pulmonary disease. Journal of Clinical Investigation, Vol.118, No.11, (November 2008), pp. 35463556, ISSN 0021-9738

Barnes, P.J. (2008) Emerging pharmacotherapies for COPD. Chest, Vol. 134, No. 6, (December 2008), pp. 1278-1286, ISSN 0012-3692

Bhavsar, P., Hew, M., Khorasani, N., Torrego, A., Barnes, P.J., Adcock, I., \& Chung, K.F. (2008). Relative corticosteroid insensitivity of alveolar macrophages in severe asthma compared to non-severe asthma. Thorax, Vol.63, No.9, (September 2008), pp. 784-790, ISSN 0040-6376

Bosken, C.H., Wiggs, B.R., Pare, P.D., \& Hogg, J.C. (1990). Small airway dimensions in smokers with obstruction to airflow. American Review of Respiratory Disease, Vol.142, No.3, (September 1990), pp. 563-570, ISSN 0003-0805

Bousquet, J., Lacoste, J.Y., Chanez, P., Vic, P., Godard, P., \& Michel, F.B. (1996). Bronchial elastic fibers in normal subjects and asthmatic patients. American Journal of Respiratory and Critical Care Medicine, Vol.153, No.5, (May 1996), pp. 1648-1654, ISSN 1073-449X

Bousquet, J., Aubier, M., Sastre, J., Izquierdo, J.L., Adler, L.M., Hofbauer, P., Rost K,D., Harnest, U., Kroemer, B., Albrecht, A., \& Bredenbröker, D. (2006). Comparison of roflumilast, an oral antiinflammatory, with beclomethasone dipropionate in the treatment of persistent asthma. Allergy, Vol.61, No.1, (January 2006), pp. 72-78, ISSN 0105-4538

Bullens, D.M., Truyen, E., Coteur, L., Dilissen, E., Hellings, P.W., Dupont, L.J., \& Ceuppens, J.L. (2006). IL-17 mRNA in sputum of asthmatic patients: linking $\mathrm{T}$ cell driven inflammation and granulocytic influx? Respiratory Research, Vol.7, (November 2006), pp. 135, ISSN 1465-9921

Calverley, P,M., Burge, P,S., Spencer, S., Anderson, J,A., \& Jones, P,W. (2003). Bronchodilator reversibility testing in chronic obstructive pulmonary disease. Thorax, Vol.58, No.8, (August 2003), pp. 659-664, ISSN 0040-6376 
Calverley, P.M., Sanchez-Toril, F., McIvor, A., Teichmann, P., Bredenbroeker, D., \& Fabbri, L.M. (2007). Effect of 1-year treatment with roflumilast in severe chronic obstructive pulmonary disease. American Journal of Respiratory and Critical Care Medicine, Vol.176, No.2, (July 2007), pp. 154-161, ISSN 1073-449X

Calverley, P.M., Rabe, K.F., Goehring, U.M., Kristiansen, S., Fabbri, L.M., \& Martinez F,J.; M2-124 and M2-125 study groups. (2009). Roflumilast in symptomatic chronic obstructive pulmonary disease: two randomised clinical trials. Lancet, Vol.374, No.9691, (August 2009), pp. 685-694, ISSN 0140-6736

Caruso, M., Tringali, G., \& Polosa, R. (2007). Evidence for a functional contribution of adenosine signalling in inflammatory airway diseases. Current Medicinal Chemistry Immunology, Endocrine \& Metabolic Agents, Vol.7, No.4 (August 2007), pp. 286-297, ISSN 1568-0134

Cazzola, M. \& Matera. M.G. (2009). Emerging inhaled bronchodilators: an update. European Respiratory Journal, Vol.34, No.3, (September 2009), pp. 757-769, ISSN 0903-1936

Chiba, Y., Todoroki. M., Nishida, Y., Tanabe, M., \& Misawa M. (2009). A novel STAT6 inhibitor AS1517499 ameliorates antigen-induced bronchial hypercontractility in mice. American Journal of Respiratory Cell and Molecular Biology, Vol.41, No.5, (November 2009), pp. 516-524, ISSN 1044-1549

Chung. K.F. (2006). Phosphodiesterase inhibitors in airways disease. European Journal of Pharmacology, Vol.533, No.1-3, (March 2006), pp. 110-117, ISSN 0014-2999

Cox, G. (1995). Glucocorticoid treatment inhibits apoptosis in human neutrophils. Separation of survival and activation outcomes. Journal of Immunology, Vol.154, No.9, (May 1995), pp. 4719-4725, ISSN 0022-1767

Cuenda, A. \& Rousseau, S. (2007). p38 MAP-kinases pathway regulation, function and role in human diseases. Biochimica et Biophysica Acta, Vol.1773, No.8, (August 2007), pp. 1358-1375, ISSN 0006-3002

Culpitt, S.V., Maziak, W., Loukidis, S., Nightingale, J.A., Matthews, J.L., \& Barnes, P.J. (1999). Effect of high dose inhaled steroid on cells, cytokines, and proteases in induced sputum in chronic obstructive pulmonary disease. American Journal of Respiratory and Critical Care Medicine, Vol.160, No.5 Pt 1, (November 1999), pp. 1635-1639, ISSN 1073-449X

Cundall, M., Sun, Y., Miranda, C., Trudeau, J.B., Barnes, S., \& Wenzel, S.E. (2003). Neutrophil-derived matrix metalloproteinase- 9 is increased in severe asthma and poorly inhibited by glucocorticoids. Journal of Allergy and Clinical Immunology, Vol.112, No.6, (December 2003), pp. 1064-1071, ISSN 0091-6749

Curtis, J.L., Freeman, C.M., \& Hogg, J.C. (2007). The immunopathogenesis of chronic obstructive pulmonary disease: insights from recent research. Proceedings of the American Thoracic Society, Vol.4, No.7, (October 2007), pp. 512-521, ISSN 1546-3222

Evans, D.J., Barnes, P.J., Spaethe, S.M., van Alstyne, E.L., Mitchell, M.I., \& O'Connor, B.J. (1996). The effect of a leukotriene B4 antagonist LY293111 on allergen- induced responses in asthma. Thorax, Vol.51, No.12, (December 1996), pp. 1178-1184, ISSN 0040-6376

Fahy, J.V., Kim, K.W., Liu, J., \& Boushey, H.A. (1995). Prominent neutrophilic inflammation in sputum from subjects with asthma exacerbation. Journal of Allergy and Clinical Immunology, Vol.95, No.4, (April 1995), pp. 843-852, ISSN 0091-6749 
Foley, S.C. \& Hamid, Q. (2007). Images in allergy and immunology: neutrophils in asthma. Journal of Allergy and Clinical Immunology, Vol.119, No.5, (May 2007), pp. 1282-1286, ISSN 0091-6749

Gibson, P.G. \& Simpson, J.L. (2009). The overlap syndrome of asthma and COPD: what are its features and how important is it? Thorax, Vol.64, No.8, (August 2009), pp. 728735, ISSN 0040-6376

Guerra, S. (2005). The overlap of asthma and chronic obstructive pulmonary disease. Current Opinion in Pulmonary Medicine, Vol.11, No.1, (January 2005), pp. 7-13, ISSN 10705287

Haldar, P., Brightling, C.E., Hargadon, B., Gupta, S., Monteiro, W., Sousa, A., Marshall, R.P., Bradding, P., Green, R.H., Wardlaw, A.J., \& Pavord, I.D. (2009). Mepolizumab and exacerbations of refractory eosinophilic asthma. New England Journal of Medicine, Vol.360, No.10, (March 2009), pp. 973-984, ISSN 0028-4793

James, A.L., \& Wenzel, S. (2007). Clinical relevance of airway remodelling in airway diseases. European Respiratory Journal, Vol.30, No.1, (July 2007), pp. 134-155, ISSN 0903-1936

Jeffery, P.K. (2004). Remodeling and inflammation of bronchi in asthma and chronic obstructive pulmonary disease. Proceedings of the American Thoracic Society, Vol.1, No.3, (November 2004), pp. 176-183, ISSN 1546-3222

Kamath, A.V., Pavord, I.D., Ruparelia, P.R., \& Chilvers, E.R. (2005). Is the neutrophil the key effector cell in severe asthma? Thorax, Vol.60, No.7, (July 2005), pp. 529-530, ISSN 0040-6376

Karin, M. Yamamoto, Y., \& Wang, QM. (2004). The IKK NF-kappa B system: a treasure trove for drug development. Nat Reviews Drug Discovery, Vol.3, No.1, (January 2004), pp. 17-26, ISSN 1474-1776

Keatings, V.M., Jatakanon, A., Worsdell, Y.M., \& Barnes, P.J. (1997). Effects of inhaled and oral glucocorticoids on inflammatory indices in asthma and COPD. American Journal of Respiratory and Critical Care Medicine, Vol.155, No.2, (Febuary1997), pp. 542-548, ISSN 1073-449X

Kerstjens, H.A., Brand, P.L., Quanjer, P.H., van der Bruggen-Bogaarts, B.A., Koëter, G.H., \& Postma, D.S. (1993). Variability of bronchodilator response and effects of inhaled corticosteroid treatment in obstructive airways disease. Dutch CNSLD Study Group. Thorax, Vol.48, No.7, (July 1993), pp. 722-729, ISSN 0040-6376

Kim, S.R. \& Rhee, Y.K. (2010). Overlap Between Asthma and COPD: Where the Two Diseases Converge. Allergy, Asthma \& Immunology Research, Vol.2, No.4, (October 2010), pp. 209-214, ISSN 2092-7355

Kraft, M., Djukanovic, R., Wilson, S., Holgate, S.T., \& Martin, R.J. (1996). Alveolar tissue inflammation in asthma. American Journal of Respiratory and Critical Care Medicine, Vol.154, No.5, (November 1996), pp. 1505-1510, ISSN 1073-449X

Kraft, M., Martin, R.J., Wilson, S., Djukanovic, R., \& Holgate, S.T. (1999). Lymphocyte and eosinophil influx into alveolar tissue in nocturnal asthma. American Journal of Respiratory and Critical Care Medicine, Vol.159, No.1, (January 1999), pp. 228-234, ISSN 1073-449X

Lamblin, C., Gosset, P., Tillie-Leblond, I., Saulnier, F., Marquette, C.H., Wallaert, B., \& Tonnel, A.B. (1998). Bronchial neutrophilia in patients with noninfectious status 
asthmaticus. American Journal of Respiratory and Critical Care Medicine, Vol.157, No.2, (Febuary 1998), pp. 394-402, ISSN 1073-449X

Lee, K.S., Kim, S.R., Park, H.S., Park, S.J., Min, K.H., Lee, K.Y., Jin, S.M., \& Lee, Y.C. (2007). Cysteinyl leukotriene upregulates IL-11 expression in allergic airway disease of mice. Journal of Allergy and Clinical Immunology, Vol.119, No.1, (January 2007), pp. 141-149, ISSN 0091-6749

Louis, R. \& Djukanovic, R. (2006). Is the neutrophil a worthy target in severe asthma and chronic obstructive pulmonary disease? Clinical E Experimental Allergy, Vol.36, No.5, (February 2006), pp. 563-567, ISSN 0954-7894

Matsunaga, K., Yanagisawa, S., Ichikawa, T., Ueshima, K., Akamatsu, K., Hirano, T., Nakanishi, M., Yamagata, T., Minakata, Y., \& Ichinose, M. (2006). Airway cytokine expression measured by means of protein array in exhaled breath condensate: correlation with physiologic properties in asthmatic patients. Journal of Allergy and Clinical Immunology, Vol.118, No.1, (July 2006), pp. 84-90, ISSN 0091-6749

Mauad, T. \& Dolhnikoff, M. (2008). Pathologic similarities and differences between asthma and chronic obstructive pulmonary disease. Current Opinion in Pulmonary Medicine, Vol.14, No.1, (January 2008), pp. 31-38, ISSN 1070-5287

Molet, S., Hamid, Q., Davoine, F., Nutku, E., Taha, R., Pagé, N., Olivenstein, R., Elias, J., \& Chakir, J. (2001). IL-17 is increased in asthmatic airways and induces human bronchial fibroblasts to produce cytokines. Journal of Allergy and Clinical Immunology, Vol.108, No.3, (September 2001), pp. 430-438, ISSN 0091-6749

Nagai, A., West, W.W., \& Thurlbeck, W.M. (1985). The National Institutes of Health Intermittent Positive-Pressure Breathing trial: pathology studies. II. Correlation between morphologic findings, clinical findings, and evidence of expiratory airflow obstruction. American Review of Respiratory Disease, Vol.132, No.5, (November 1985), pp. 946-953, ISSN 0003-0805

Nair, P., Pizzichini, M.M., Kjarsgaard, M., Inman, M.D., Efthimiadis, A., Pizzichini, E., Hargreave, F.E., \& O'Byrne, P.M. (2009). Mepolizumab for prednisone-dependent asthma with sputum eosinophilia. New England Journal of Medicine, Vol.360, No.10, (March 2009), pp. 985-993, ISSN 0028-4793

Park, H.W., Yang, M.S., Park, C.S., Kim, T.B., Moon, H.B., Min, K.U., Kim, Y.Y., \& Cho, S.H. (2009). Additive role of tiotropium in severe asthmatics and Arg16Gly in ADRB2 as a potential marker to predict response. Allergy, Vol.64, No.5, (May 2009), pp. 778783, ISSN 0954-7894

Park, S.J., Lee, K.S., Kim, S.R., Min, K.H., Moon, H., Lee, M.H., Chung, C.R., Han, H.J., Puri, K.D., \& Lee, Y.C. (2010). Phosphoinositide 3-kinase $\delta$ inhibitor suppresses interleukin-17 expression in a murine asthma model. European Respiratory Journal, Vol.36, No.6, (December 2010), pp. 1448-1459, ISSN 0903-1936

Polosa, R. \& Blackburn, M.R. (2009). Adenosine receptors as targets for therapeutic intervention in asthma and chronic obstructive pulmonary disease. Trends in Pharmacological Sciences, Vol.30, No.10, (October 2009), pp. 528-535, ISSN 0165-6147

Prause, O., Bozinovski, S., Anderson, G.P., \& Linden, A. (2004). Increased matrix metalloproteinase-9 concentration and activity after stimulation with interleukin-17 in mouse airways. Thorax, Vol.59, No.4, (April 2004), pp. 313-317, ISSN 0040-6376

Rabe, K.F., Bateman. E.D., O'Donnell. D., Witte. S., Bredenbroker, D., \& Bethke, T.D. (2005). Roflumilast-an oral anti-inflammatory treatment for chronic obstructive 
pulmonary disease: a randomised controlled trial. Lancet, Vol.366, No.9485, (August 2005), pp. 563-571, ISSN 0140-6736

Saet, M., Di Stefano, A., Maestrelli, P., Turato, G., Ruggieri, M,P., Roggeri, A., Calcagni, P., Mapp, C.E., Ciaccia, A., \& Fabbri, L.M. (1994). Airway eosinophilia in chronic bronchitis during exacerbations. American Journal of Respiratory and Critical Care Medicine, Vol.150, No.6 Pt 1, (December 1994), pp. 1646-1652, ISSN 1073-449X

Schaecke, H., Schottelius, A., Döcke, W.D., Strehlke, P., Jaroch, S., Schmees, N., Rehwinkel, H., Hennekes, H., \& Asadullah, K. (2004). Dissociation of transactivation from transrepression by a selective glucocorticoid receptor agonist leads to separation of therapeutic effects from side effects. Proceedings of the National Academy of Sciences of the United States of America, Vol.101, No.1, (Junuary 2004), pp. 227-232, ISSN 00278424

Schleimer, R.P., Freeland, H.S., Peters, S.P., Brown, K.E., \& Derse, C.P. (1989). An assessment of the effects of glucocorticoids on degranulation, chemotaxis, binding to vascular endothelium and formation of leukotriene B4 by purified human neutrophils. Journal of Pharmacology and Experimental Therapeutics, Vol.250, No.2, (August 1989), pp. 598-605, ISSN 0022-3565

Shirtcliffe, P., Weatherall, M., Travers, J., \& Beasley, R. (2011). The multiple dimensions of airways disease: targeting treatment to clinical phenotypes. Current Opinion in Pulmonary Medicine, Vol.11, No.17, (March 2011), pp. 272-278, ISSN 1070-5287

Spurzem, J.R., \& Rennard, S.I. (2005). Pathogenesis of COPD. Seminars in Respiratory and Critical Care Medicine, Vol.26, No.2, (April 2005), pp. 142-153, ISSN 1069-3424

Stein, R.T., Holberg, C.J., Sherrill, D., Wright, A.L., Morgan, W.J., Taussig, L., \& Martinez, F.D. (1999). Influence of parental smoking on respiratory symptoms during the first decade of life: the Tucson Children's Respiratory Study. American Journal of Epidemiology, Vol.149, No.11, (June 1999), pp. 1030-1037, ISSN 0002-9262

Stern, D.A., Morgan, W.J., \& Wright, A.L. (2007). Poor airwayin early infancy and lung function by age 22 years: a non-selective longitudinal cohort study. Lancet, Vol.370, No.9589, (September 2007), pp. 758-764, ISSN 0140-6736

Sutherland, E.R., Martin, R.J., Bowler, R.P., Zhang, Y., Rex, M.D., \& Kraft, M. (2004). Physiologic correlates of distal lung inflammation in asthma. Journal of Allergy and Clinical Immunology, Vol.113, No.6, (June 2004), pp. 1046-1050, ISSN 0091-6749

Tashkin, D.P., Altose, M.D., Connett, J.E., Kanner, R.E., Lee, W.W., \& Wise, R.A. (1996). Methacholine reactivity predicts changes in lung function over time in smokers with early chronic obstructive pulmonary disease. The Lung Health Study Research Group. American Journal of Respiratory and Critical Care Medicine, Vol.153, No.6 Pt 1, (Jun 1996), pp. (1802-1811), ISSN 1073-449X

To, Y., Ito, K., Kizawa, Y., Failla, M., Ito, M., Kusama, T., Elliott, W.M., Hogg, J.C., Adcock, I.M., \& Barnes, P.J. (2010). Targeting phosphoinositide-3-kinase-d with theophylline reverses corticosteroid insensitivity in COPD. American Journal of Respiratory and Critical Care Medicine, Vol.182, No.7, (October 2010), pp. 897-904. ISSN 1073-449X

Torphy, T.J. (1988). Action of mediators on airway smooth muscle: functional antagonism as a mechanism for bronchodilator drugs. Agents and Actions Supplments, Vol.23, (1988), pp. 37-53, ISSN 0379-0363 
Torphy, T.J. (1998). Phosphodiesterase isozymes: molecular targets for novel antiasthma agents. American Journal of Respiratory and Critical Care Medicine, Vol.157, No.2, (February 1998), pp. 351-370, ISSN 1073-449X

Torphy, T.J. \& Cieslinski, L.B. (1990). Characterization and selective inhibition of cyclic nucleotide phosphodiesterase isozymes in canine tracheal smooth muscle. Molecular Pharmacology, Vol.37, No.2, (February 1990), pp. 206-214, ISSN 0026-895X

Torphy, T.J. \& Undem, B.J. (1991). Phosphodiesterase inhibitors: new opportunities for the treatment of asthma. Thorax, Vol.46, No.7, (July 1991), pp. 512-523, ISSN 0040-6376

Tsokos, M. \& Paulsen, F. (2002). Expression of pulmonary lactoferrin in sudden-onset and slow-onset asthma with fatal outcome. Virchows Archiv, Vol.441, No.5, (November 2002), pp. 494-499, ISSN 0945-6317

Vonk, J.M., Jongepier, H., Panhuysen, C.I., Schouten, J.P., Bleecker, E.R., \& Postma, D.S. (2003). Risk factors associated with the presence of irreversible airflow limitation and reduced transfer coefficient in patients with asthma after 26 years of follow up. Thorax, Vol.58, No.4, (April 2003), pp. 322-327, ISSN 0040-6376

Wark, P.A., Johnston, S.L., Moric, I., Simpson, J.L., Hensley, M.J., \& Gibson, P.G. (2002). Neutrophil degranulation and cell lysis is associated with clinical severity in virusinduced asthma. European Respiratory Journal, Vol.19, No.1, (January 2002), pp. 6875, ISSN 0903-1936

Wenzel, S., Wilbraham, D., Fuller, R., Getz, E.B., \& Longphre, M. (2007). Effect of an interleukin-4 variant on late phase asthmatic response to allergen challenge in asthmatic patients: results of two phase 2a studies. Lancet, Vol.370, No.9596, (October 2007), pp. 1422-1431, ISSN 0140-6736

Wenzel, S.E., Balzar, S., Cundall, M., \& Chu, H.W. (2003). Subepithelial basement membrane immunoreactivity for matrix metalloproteinase 9: association with asthma severity, neutrophilic inflammation, and wound repair. Journal of Allergy and Clinical Immunology, Vol.111, No.6, (June 2003), pp. 1345-1352, ISSN 0091-6749

Wong, C.K., Ho, C.Y., Ko, F.W., Chan, C.H., Ho, A.S., Hui, D.S., \& Lam, C.W. (2001). Proinflammatory cytokines (IL-17, IL-6, IL-18 and IL-12) and Th cytokines (IFN-ץ, IL-4, IL-10 and IL-13) in patients with allergic asthma. Clinical \& Experimantal Immunology, Vol.125, No.2, (August 2001), pp. 177-183, ISSN 0009-9104

Wright, J.L., Lawson, L.M., Pare, P.D., Wiggs, B.J., Kennedy, S., \& Hogg, J.C. (1983). Morphology of peripheral airways in current smokers and ex-smokers. American Review of Respiratory Disease, Vol.127, No.4, (April 1983), pp. 474-477, ISSN 00030805

Xystrakis, E., Kusumakar, S., Boswell, S., Peek, E., Urry, Z., Richards, D.F., Adikibi, T., Pridgeon, C., Dallman, M., Loke, T.K., Robinson, D.S., Barrat, F.J., O'Garra, A., Lavender, P., Lee, T.H., Corrigan, C., \& Hawrylowicz, C.M. (2006). Reversing the defective induction of IL-10-secreting regulatory $\mathrm{T}$ cells in glucocorticoid-resistant asthma patients. Journal of Clinical Investigation, Vol.116, No.1, (January 2006), pp. 146-155, ISSN 0021-9738

Zheng, T., Zhu, Z., Wang, Z., Homer, R.J., Ma, B., Riese, R.J. Jr., Chapman, H.A. Jr., Shapiro, S.D., \& Elias, J.A. (2000). Inducible targeting of IL-13 to the adult lung causes matrix metalloproteinase- and cathepsin-dependent emphysema. Journal of Clinical Investigation, Vol.106, No.9, (November 2000), pp. 1081-1093, ISSN 0021-9738 
Zhou, Y., Schneider, D.J, Blackburn, M.R. (2009). Adenosine signaling and the regulation of chronic lung disease. Pharmacology \& Therapeutics, Vol.123, No.1, (July 2009), pp. 105-116, ISSN 0163-7258

Zhu, J., Qiu, Y.S., Majumdar, S., Gamble, E., Matin, D., Turato, G., Fabbri, L.M., Barnes, N., Saetta, M., \& Jeffery, P.K. (2001). Exacerbations of bronchitis: bronchial eosinophilia and gene expression for interleukin-4, interleukin-5, and eosinophil chemoattractants. American Journal of Respiratory and Critical Care Medicine, Vol.164, No.1, (July 2001), pp. 109-116, ISSN 1073-449X 


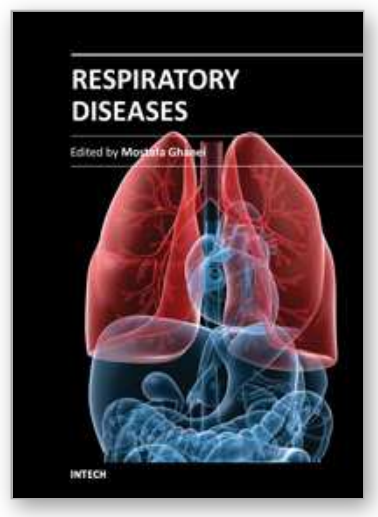

\author{
Respiratory Diseases \\ Edited by Dr. Mostafa Ghanei
}

ISBN 978-953-307-964-6

Hard cover, 242 pages

Publisher InTech

Published online 01, February, 2012

Published in print edition February, 2012

Medicine is an ever-changing science. In this regard, Respiratory medicine is not an exception and has been evolving during recent years. As new research broadens our knowledge, advanced methods for diagnoses are better understood, providing genetic and underlying pathophysiology of diseases and new clinical experiences. Consequently, publications of new resources along with revisions of previous ones are required. The book Respiratory Diseases brings practical aspects of pulmonary diseases. It contains the result of years of experience through expert clinicians in this field from different scientific centers. The respiratory diseases are discussed according to epidemiology, pathology, diagnosis, treatment, and prognosis. It includes updated resources of the pathogenesis and some molecular aspects of the aforementioned diseases and is recommended reading for all clinicians and medical students, especially pulmonologists, to access highlighted respiratory diseases in this book.

\title{
How to reference
}

In order to correctly reference this scholarly work, feel free to copy and paste the following:

So Ri Kim and Yang Keun Rhee (2012). Special Consideration in Treating Patients of Overlap Between Asthma and COPD, Respiratory Diseases, Dr. Mostafa Ghanei (Ed.), ISBN: 978-953-307-964-6, InTech, Available from: http://www.intechopen.com/books/respiratory-diseases/special-consideration-in-treatingpatients-of-overlap-between-asthma-and-copd

\section{INTECH}

open science | open minds

\section{InTech Europe}

University Campus STeP Ri

Slavka Krautzeka 83/A

51000 Rijeka, Croatia

Phone: +385 (51) 770447

Fax: +385 (51) 686166

www.intechopen.com

\section{InTech China}

Unit 405, Office Block, Hotel Equatorial Shanghai

No.65, Yan An Road (West), Shanghai, 200040, China

中国上海市延安西路65号上海国际贵都大饭店办公楼 405 单元

Phone: +86-21-62489820

Fax: $+86-21-62489821$ 
(C) 2012 The Author(s). Licensee IntechOpen. This is an open access article distributed under the terms of the Creative Commons Attribution 3.0 License, which permits unrestricted use, distribution, and reproduction in any medium, provided the original work is properly cited. 